\title{
Society Membership Trend Determinants For Sustainability: An Analysis In Insurance Industry
}

Askar Choudhury, Illinois State University, USA James Jones, Illinois State University, USA

\begin{abstract}
This study investigates the impact of age based gender effect on CPCU society membership trend. Trade associations, membership societies, and other similar groups/unions are no different than any for-profit organizations during different economic cycles, specifically during an economic downturn. When economic condition gets tough, membership related expenses can prove difficult to attain and may cause descent in the membership trend. However, demographic factors, such as, age groups and genders of society members are also factors that impact the process of society membership trend. In our analysis, after controlling for younger age groups, higher age groups are found to be instrumental in impacting the process of trend of CPCU society's membership. This suggests that gender influence on the process of society membership trend is age dependent. Furthermore, gender effect is substantially higher for older age groups in comparison to younger age groups.
\end{abstract}

Keywords: CPCU society; membership trend; society membership; gender effect; age-group effect; age-gender interaction

\section{INTRODUCTION}

$\mathrm{n}$ general, trade associations, membership societies, and other similar groups/unions are no different than any for-profit organizations during different economic cycles, specifically during an economic downturn. In tough economic condition, these organizations are trying to implement necessary steps to sustain and maintain their current business level. However, for both the members and the organizations there are some cost associated. Those who are committed to these organizations usually find the time needed to spend and the membership charge. However, when economic condition gets tough, budgeting dollars for membership can sometimes prove difficult. For industry trade associations and organizations, the goal in tough economic conditions is to show more than ever the value of the services being offered. Thus, this paper explores to identify determinants for membership fluctuations that may help the organization to device a process for their long-term sustainability.

The Chartered Property and Casualty Underwriters (CPCU) is a society committed to serve the property and casualty insurance industry professionals. These professional societies/associations are helpful to their members by providing continuous knowledge improvement, leadership skill building, and networking. The property/casualty industry in the United States operates in a regulated environment, and within the evolving American culture, consumer markets, and labor force. Thus ever changing, educational trends, demographic, litigation, consumerism, and new regulations influence the insurance industry constantly. Therefore, the need for new knowledge, and ultimately the desire and ability of insurance industry individuals to seek and attain diverse knowledge to keep up with the dynamic change in the environment requires investment in additional human capital. These societies provide opportunity to their members to develop and refine leadership skills by serving in local and national committees in leadership role. This in-turn makes these members more valuable to their employer organization. This also, provides new relationships with individuals in the same profession and hence extends professional network. This professional networking can provide insight on a work related issue or a decision making problem and its 
solution. This ability to seek assistance among the professionals from various organizations is a tremendous value to a member of the society.

The CPCU designation is awarded to individuals willing to go beyond the normal requirements of their profession. The American Institute for Chartered Property and Casualty Underwriters (AICPCU) confers the CPCU designation. This CPCU designation has been historically offered mostly in the United States, with the audience for it being the professionals within the property/casualty industry. The CPCU designation is earned through the successful completion of eight college-level courses with national essay examinations, an experience requirement, and an agreement to be bound by ethical standards. Curriculum includes risk management, insurance products, insurance operations, financial analysis, and legal and regulatory environment of insurance. Each course is accredited by the American Council on Education (ACE) for at least 3 college undergraduate credits and some for 3 graduate credits. The certification helps practitioners to make sound, ethical decisions in the complex environment of property and casualty insurance. An eight course program is tantamount to completing about 24 hours of college credits (per ACE). The CPCU society was founded in 1944, with a steady increase in membership. However, in recent years the membership trend has been in decline phase. Interestingly, the conversion rate is also in the same direction. Conversion rate is the percentage of new CPCU designees who become member of the CPCU society. Thus, the objective of this paper is to explore the determinants for society membership fluctuations.

\section{Graph-1: Plot of CPCU members over the years.}

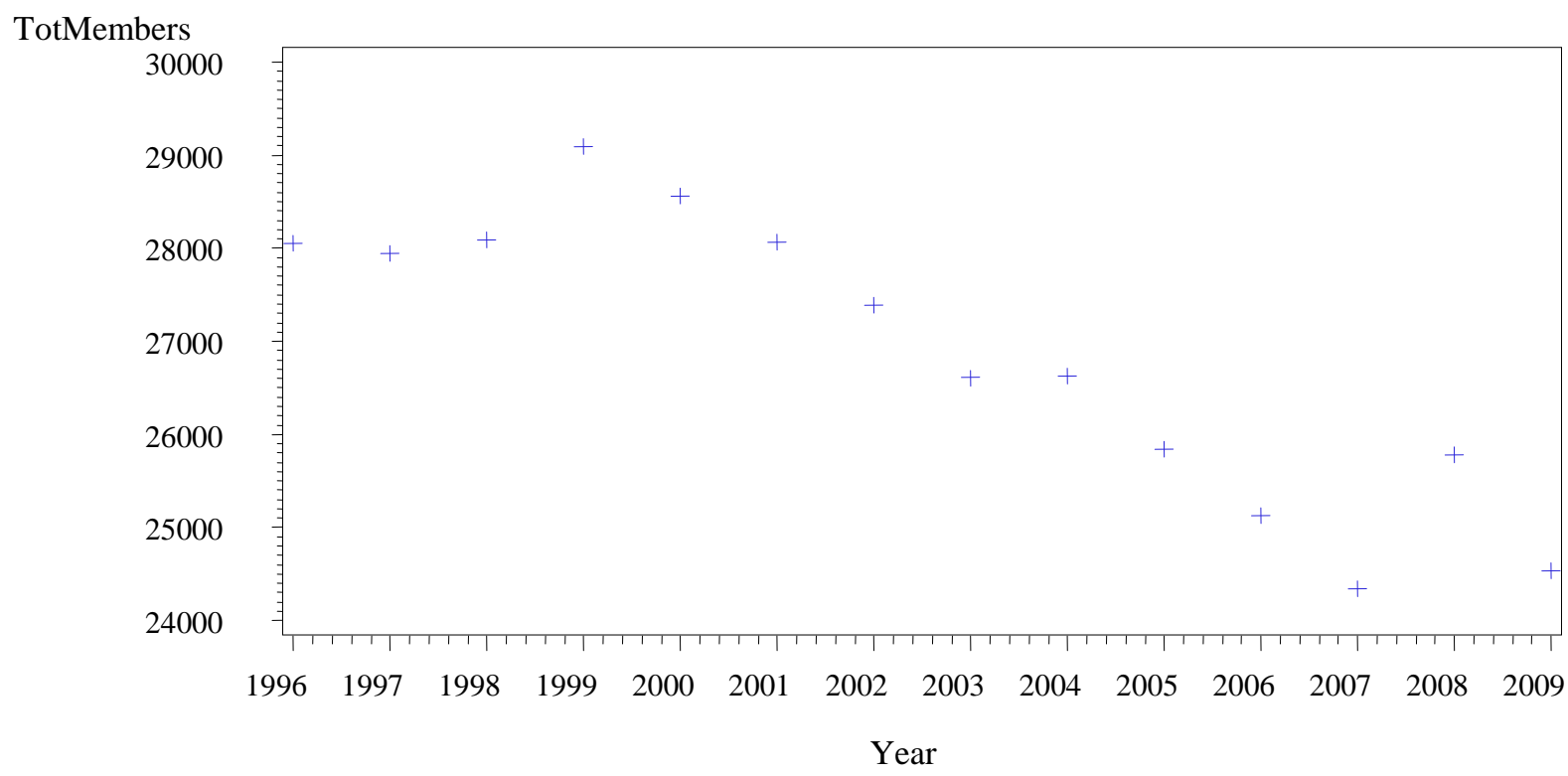

There may be numerous factors contributing to this drift in CPCU membership. The number of industry designations has continued to grow. Although these other designations may not compete directly against CPCU in terms of curriculum offered, they may compete in terms length of time required. According to the 2007 Society of Insurance Trainers and Educators Designation Handbook, there are over 200 designations and certifications. One potentially perceived substitute for the CPCU designation is the MBA degree. An MBA degree is portable to other industries and can be attained approximately the same time as a CPCU. Some companies may even hold higher value for an MBA than a CPCU designation. In examining MBAs, the most helpful comparison is comparing the growth in part-time or Executive MBA students. These students are typically working in business, often with full or partial reimbursement of their educational expenses by employers. According to the U.S. Department of Education, over 125,000 students earned MBAs in 2005. Even though the number of business schools has increased by 10 percent according to the Department of Education, the growth in the rate of part-time has been the most dramatic 
with 62 percent of schools reporting increases in enrollment and 20 percent reporting significant increases in parttime MBAs. The average age for part-time MBA enrollees is 31 years, which competes evenly with the market of people beginning to consider CPCUs. Thus, we explore the effect of GMAT takers as a substitute to MBA enrollees on the CPCU society membership.

Graph-2: Plot of conversion rate over the years.

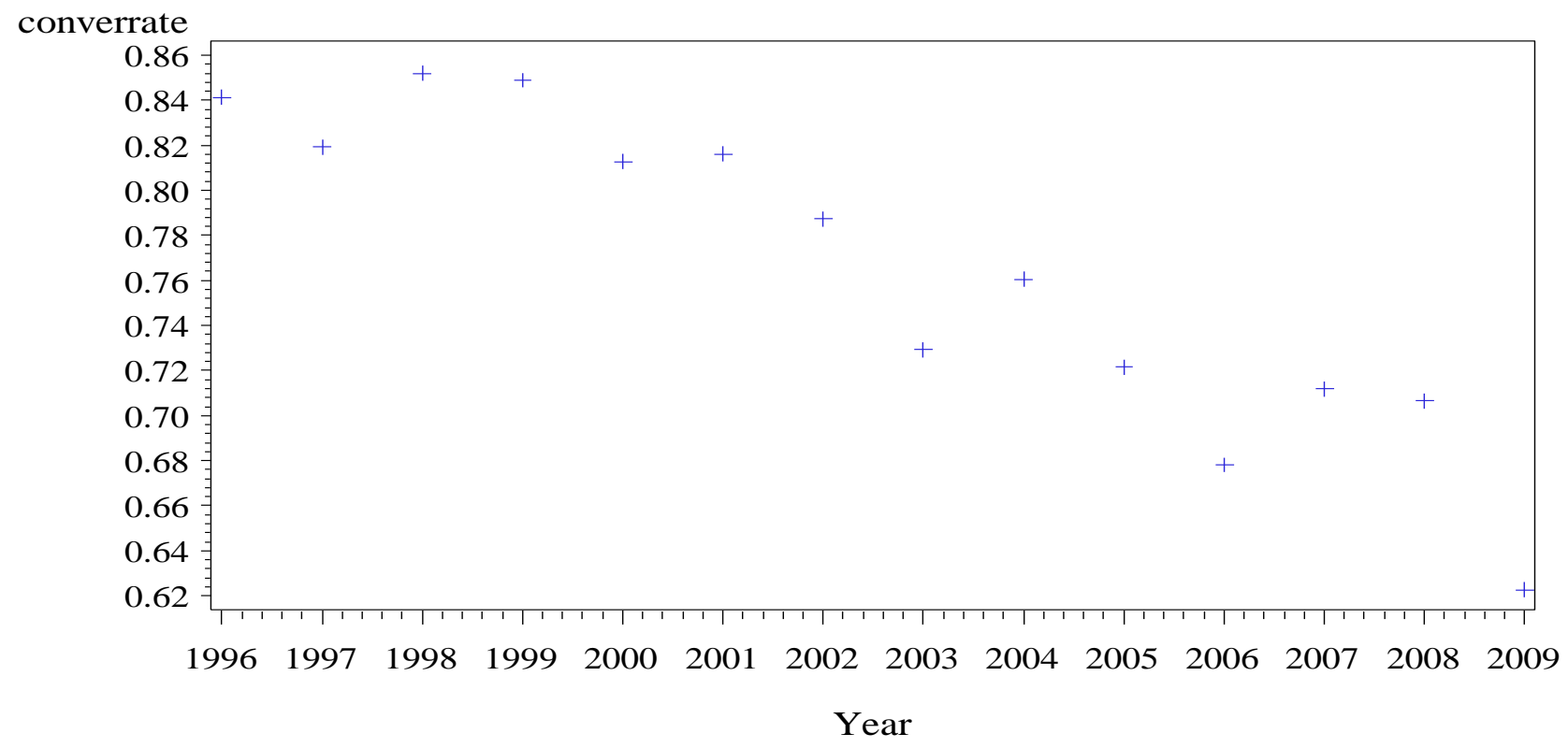

\section{LITERATURE REVIEW}

While there is considerable research done in the union membership that focuses on various factors affecting the membership fluctuations (Visser, 2006; Neumann \& Rissman, 1984; Waddington \& Whitston, 1997), very little is done in regards to the professional society membership, specifically in the insurance industry. Therefore, the primary objective of this research is to examine the determinants of membership trends within the insurance industry, specifically the CPCU society. Other studies explored political party associations (Selle 1991, Everson 1982, Klingemann and Fuchs 1998, Wattenberg 1998, Mair and Biezen 2001). Mair and Biezen (2001) found that trend fluctuations in political party association/membership may involve direct or indirect monetary gain and thus may change with the economic cycle.

Membership trend studies are done extensively in the area of labor unions (Waddington \& Whitston, 1997; Mellor, 1990). Addison and Schnabel (2003) used a survey to study the trend factors. They observed two categories of determinants; macro-determinants and micro-determinants. Macro-determinants are: price inflation, employment growth, nominal wage growth, unemployment rate/change, labor force composition, and politics. Microdeterminants include sex, age, work experience, race/nationality, education, earnings, etc. Exploratory studies on union membership are done by Kaufman and Kleiner (1993) to observe a structural shift in the labor force composition. Other studies include Scruggs and Lange (2002), Waddington and Whitston (1997), Neumann and Rissman (1984), and Mellor (1990). By applying time-series and cross-section analysis on data from 16 different industries between 1960 and 1994, Scruggs and Lane (2002) conclude that globalization do not affect the union representation. Using similar analysis, Newmann and Reder (1984) found that union membership can be impacted due to modification in political decision on social welfare. However, research studies on professional society 
membership are rare. Therefore, our research findings on CPCU society membership will add a new dimension to the area of professional membership trend analysis.

\section{DATA AND RESEARCH METHODOLOGY}

Data for this study period covers 1996-2009 on a yearly basis. The data on number of CPCU society members was collected from CPCU society and GMAT exam takers data were obtained from Graduate Management Admission Council (GMAC). Table-1 presents summary statistics of number of CPCU members and conversion rate of society members. GMAT takers data were collected for both male and female and are also reported in Table-1. Multiple regression analysis was applied to explore the significance of gender effect on the number of members separately for male and female. In addition, regression effect of number of CPCU members up to five years lag GMAT takers were explored to observe any time delayed effect of GMAT takers on CPCU society membership.

Table-1: Summary Statistics

\begin{tabular}{|c|c|c|c|c|c|c|}
\hline & $\begin{array}{c}\text { CPCU } \\
\text { Members }\end{array}$ & $\begin{array}{c}\text { Conversion } \\
\text { Rate }\end{array}$ & Gender & $\begin{array}{c}\text { GMAT } \\
\text { Exam Takers } \\
\text { AGE } 20-25\end{array}$ & $\begin{array}{c}\text { GMAT } \\
\text { Exam Takers } \\
\text { AGE } 35-39\end{array}$ & $\begin{array}{c}\text { GMAT } \\
\text { Exam Takers } \\
\text { AGE } 40-49\end{array}$ \\
\hline \multirow{2}{*}{ Minimum } & \multirow{2}{*}{23772.00} & \multirow{2}{*}{0.68} & Male & 21846.00 & 6686.00 & 4174.00 \\
\hline & & & Female & 22551.00 & 3409.00 & 2682.00 \\
\hline \multirow{2}{*}{ Maximum } & \multirow{2}{*}{29093.00} & \multirow{2}{*}{0.85} & Male & 67909.00 & 11687.00 & 7185.00 \\
\hline & & & Female & 60542.00 & 5604.00 & 4796.00 \\
\hline \multirow{2}{*}{ Mean } & \multirow{2}{*}{26656.80} & \multirow{2}{*}{0.78} & Male & 37768.21 & 9756.86 & 5613.00 \\
\hline & & & Female & 37686.50 & 4398.07 & 3510.21 \\
\hline \multirow{2}{*}{$\begin{array}{c}\text { Standard } \\
\text { Deviation }\end{array}$} & \multirow{2}{*}{1683.19} & \multirow{2}{*}{0.06} & Male & 13206.34 & 1250.30 & 883.17 \\
\hline & & & Female & 10255.82 & 624.91 & 608.29 \\
\hline
\end{tabular}

\section{Variables and Statistical Techniques}

To observe the relationship between number of CPCU members and gender-categorized GMAT takers; two separate analyses were performed. First, correlation analysis is done (see Table-2) to examine the direction of the association between factors. Second, total members (number of CPCU members) is regressed on the GMAT takers for three different age categories to observe the difference in association among age groups separately for male and female. Another set of regression models were performed with five years lag. This is to observe, if more maturity (in this case up to 5 years) and possibly more real world experience dictates the necessity to become CPCU member. Thus, there are four regression models estimated in this study. In general, it is assumed that there is a difference between younger and older people in their decision making process and therefore, different age-groups of GMAT takers are introduced into the model as independent variables. These differences may relate to members' job position, the larger amount of life experience that they have, and other personal life aspects may also play a role on the decision making process to become a society member.

Thus, a multiple regression model was run using SAS software (see, SAS/STAT User's Guide, 1993) on several different independent variables separately for male and female. These separate analyses by gender are to observe the differential effect of gender on membership trend due to age-group differences. This measure is designed to test the hypothesis that membership fluctuation is both age and gender dependent. Specification of the regression models are of the following form:

Total_Members $=\beta_{0}+\beta_{1} G M A T \_20-25+\beta_{2} G M A T_{-} 35-39+\beta_{3} G M A T \_40-49$

Where:

Total_Members: Total number of members each year.

GMAT_20-25: number of GMAT takers for the age group of 20-25 years, 
GMAT_35-39: number of GMAT takers for the age group of 35-39 years, GMAT_40-49: number of GMAT takers for the age group of 40-49 years,

Multiple regression model is often appropriate for continuous and/or categorical predictor variable $(X)$ with a continuous response $(Y)$. Method of least squares or a method of maximum likelihood for normal population is primarily used. Further discussions on different estimation methods can be found in Choudhury, Hubata and St. Louis (1999), and Choudhury (1994).

Table-2: Correlation Matrix

\begin{tabular}{|c|c|c|c|c|c|c|c|c|c|}
\hline & & $\begin{array}{c}\text { CPCU } \\
\text { Member }\end{array}$ & $\begin{array}{c}\text { Conversio } \\
\text { n } \\
\text { Rate }\end{array}$ & $\begin{array}{c}\text { GMAT } \\
20-25\end{array}$ & $\begin{array}{c}\text { GMAT } \\
\text { 35-39 }\end{array}$ & $\begin{array}{c}\text { GMAT } \\
40-49\end{array}$ & $\begin{array}{c}5 \text { years } \\
\text { Lagged } \\
\text { GMAT } \\
20-25\end{array}$ & $\begin{array}{c}5 \text { years } \\
\text { Lagged } \\
\text { GMAT } \\
35-39\end{array}$ & $\begin{array}{c}5 \text { years } \\
\text { Lagged } \\
\text { GMAT } \\
40-49\end{array}$ \\
\hline \multirow{2}{*}{$\begin{array}{c}\text { CPCU } \\
\text { Members }\end{array}$} & Male & 1.00000 & $\begin{array}{c}0.93379 \\
<.0001\end{array}$ & $\begin{array}{c}-0.7820 \\
0.0016\end{array}$ & $\begin{array}{c}0.30231 \\
0.3154\end{array}$ & $\begin{array}{c}0.58655 \\
0.0351\end{array}$ & $\begin{array}{c}0.48738 \\
0.0771\end{array}$ & $\begin{array}{c}-0.41864 \\
0.1363\end{array}$ & $\begin{array}{c}0.47525 \\
0.0859\end{array}$ \\
\hline & Female & 1.00000 & $\begin{array}{c}0.93379 \\
<.0001\end{array}$ & $\begin{array}{c}-0.7551 \\
0.0028\end{array}$ & $\begin{array}{c}0.58530 \\
0.0356\end{array}$ & $\begin{array}{c}0.61051 \\
0.0267\end{array}$ & $\begin{array}{c}0.33255 \\
0.2453\end{array}$ & $\begin{array}{c}0.42476 \\
0.1301\end{array}$ & $\begin{array}{c}0.54779 \\
0.0426\end{array}$ \\
\hline \multirow{2}{*}{$\begin{array}{c}\text { Conversion } \\
\text { Rate }\end{array}$} & Male & $\begin{array}{c}0.93379 \\
<.0001 \\
\end{array}$ & 1.00000 & $\begin{array}{c}-0.7325 \\
0.0044\end{array}$ & $\begin{array}{c}0.23246 \\
0.4447\end{array}$ & $\begin{array}{c}0.58787 \\
0.0346\end{array}$ & $\begin{array}{c}0.58493 \\
0.0280\end{array}$ & $\begin{array}{c}-0.33238 \\
0.2456\end{array}$ & $\begin{array}{c}0.53543 \\
0.0485\end{array}$ \\
\hline & Female & $\begin{array}{c}0.93379 \\
<.0001 \\
\end{array}$ & 1.00000 & $\begin{array}{c}-0.7131 \\
0.0062\end{array}$ & $\begin{array}{c}0.61426 \\
0.0255\end{array}$ & $\begin{array}{c}0.61425 \\
0.0255\end{array}$ & $\begin{array}{c}0.42364 \\
0.1312\end{array}$ & $\begin{array}{c}0.49181 \\
0.0741\end{array}$ & $\begin{array}{c}0.59054 \\
0.0262\end{array}$ \\
\hline \multirow{2}{*}{$\begin{array}{c}\text { GMAT } \\
\mathbf{2 0 - 2 5}\end{array}$} & Male & $\begin{array}{c}-0.78203 \\
0.0016\end{array}$ & $\begin{array}{c}-0.73250 \\
0.0044\end{array}$ & 1.00000 & $\begin{array}{c}-0.1377 \\
0.6536\end{array}$ & $\begin{array}{c}-0.34951 \\
0.2418\end{array}$ & $\begin{array}{c}-0.23787 \\
0.4339\end{array}$ & $\begin{array}{c}0.45890 \\
0.1147\end{array}$ & $\begin{array}{c}-0.23405 \\
0.4415\end{array}$ \\
\hline & Female & $\begin{array}{c}-0.75506 \\
0.0028\end{array}$ & $\begin{array}{c}-0.71306 \\
0.0062\end{array}$ & 1.00000 & $\begin{array}{c}-0.1948 \\
0.5235\end{array}$ & $\begin{array}{c}-0.27004 \\
0.3722\end{array}$ & $\begin{array}{c}-0.11341 \\
0.7122\end{array}$ & $\begin{array}{c}-0.25012 \\
0.4098\end{array}$ & $\begin{array}{c}-0.28816 \\
0.3397 \\
\end{array}$ \\
\hline \multirow{2}{*}{$\begin{array}{c}\text { GMAT } \\
\text { 35-39 }\end{array}$} & Male & $\begin{array}{c}0.30231 \\
0.3154\end{array}$ & $\begin{array}{c}0.23246 \\
0.4447\end{array}$ & $\begin{array}{c}-0.1377 \\
0.6536\end{array}$ & 1.00000 & $\begin{array}{c}0.83538 \\
0.0004\end{array}$ & $\begin{array}{c}-0.19059 \\
0.5328\end{array}$ & $\begin{array}{c}-0.24024 \\
0.4292\end{array}$ & $\begin{array}{c}-0.07542 \\
0.8066\end{array}$ \\
\hline & Female & $\begin{array}{c}0.58530 \\
0.0356\end{array}$ & $\begin{array}{c}0.61426 \\
0.0255\end{array}$ & $\begin{array}{c}-0.1948 \\
0.5235\end{array}$ & 1.00000 & $\begin{array}{c}0.96391 \\
<.0001\end{array}$ & $\begin{array}{c}0.26887 \\
0.3744\end{array}$ & $\begin{array}{c}0.31867 \\
0.2886\end{array}$ & $\begin{array}{c}0.40569 \\
0.1690\end{array}$ \\
\hline \multirow{2}{*}{$\begin{array}{c}\text { GMAT } \\
40-49\end{array}$} & Male & $\begin{array}{c}0.58655 \\
0.0351\end{array}$ & $\begin{array}{c}0.58787 \\
0.0346\end{array}$ & $\begin{array}{c}-0.3495 \\
0.2418\end{array}$ & $\begin{array}{c}0.83538 \\
0.0004\end{array}$ & 1.00000 & $\begin{array}{c}0.25464 \\
0.4011\end{array}$ & $\begin{array}{c}-0.20775 \\
0.4958\end{array}$ & $\begin{array}{c}0.26152 \\
0.3881\end{array}$ \\
\hline & Female & $\begin{array}{c}0.61051 \\
0.0267\end{array}$ & $\begin{array}{c}0.61425 \\
0.0255\end{array}$ & $\begin{array}{c}-0.2700 \\
0.3722\end{array}$ & $\begin{array}{c}0.96391 \\
<.0001\end{array}$ & 1.00000 & $\begin{array}{c}0.21477 \\
0.4810\end{array}$ & $\begin{array}{c}0.28743 \\
0.3410\end{array}$ & $\begin{array}{c}0.33483 \\
0.2634\end{array}$ \\
\hline \multirow{2}{*}{$\begin{array}{c}\text { GMAT } \\
20-25 \\
\text { 5yrs lagged }\end{array}$} & Male & $\begin{array}{c}0.48738 \\
0.0771\end{array}$ & $\begin{array}{c}0.58493 \\
0.0280\end{array}$ & $\begin{array}{c}-0.2378 \\
0.4339\end{array}$ & $\begin{array}{c}-0.1906 \\
0.5328\end{array}$ & $\begin{array}{c}0.25464 \\
0.4011\end{array}$ & 1.00000 & $\begin{array}{c}0.33896 \\
0.2358\end{array}$ & $\begin{array}{c}0.88500 \\
<.0001\end{array}$ \\
\hline & Female & $\begin{array}{c}0.33255 \\
0.2453\end{array}$ & $\begin{array}{c}0.42364 \\
0.1312\end{array}$ & $\begin{array}{c}-0.1134 \\
0.7122\end{array}$ & $\begin{array}{c}0.26887 \\
0.3744\end{array}$ & $\begin{array}{c}0.21477 \\
0.4810\end{array}$ & 1.00000 & $\begin{array}{c}0.88262 \\
<.0001\end{array}$ & $\begin{array}{c}0.86698 \\
<.0001\end{array}$ \\
\hline \multirow{2}{*}{$\begin{array}{c}\text { GMAT } \\
\text { 35-39 } \\
\text { 5yrs lagged }\end{array}$} & Male & $\begin{array}{c}-0.41864 \\
0.1363\end{array}$ & $\begin{array}{c}-0.33238 \\
0.2456\end{array}$ & $\begin{array}{c}0.45890 \\
0.1147\end{array}$ & $\begin{array}{c}-0.2402 \\
0.4292\end{array}$ & $\begin{array}{c}-0.20775 \\
0.4958\end{array}$ & $\begin{array}{c}0.33896 \\
0.2358\end{array}$ & 1.00000 & $\begin{array}{c}0.55740 \\
0.0384\end{array}$ \\
\hline & Female & $\begin{array}{c}0.42476 \\
0.1301\end{array}$ & $\begin{array}{c}0.49181 \\
0.0741\end{array}$ & $\begin{array}{c}-0.2501 \\
0.4098\end{array}$ & $\begin{array}{c}0.31867 \\
0.2886\end{array}$ & $\begin{array}{c}0.28743 \\
0.3410\end{array}$ & $\begin{array}{c}0.88262 \\
<.0001\end{array}$ & 1.00000 & $\begin{array}{c}0.96176 \\
<.0001 \\
\end{array}$ \\
\hline \multirow{2}{*}{$\begin{array}{c}\text { GMAT } \\
40-49 \\
\text { 5yrs lagged }\end{array}$} & Male & $\begin{array}{c}0.47525 \\
0.0859\end{array}$ & $\begin{array}{c}0.53543 \\
0.0485\end{array}$ & $\begin{array}{c}-0.2341 \\
0.4415\end{array}$ & $\begin{array}{c}-0.0754 \\
0.8066\end{array}$ & $\begin{array}{c}0.26152 \\
0.3881\end{array}$ & $\begin{array}{c}0.88500 \\
<.0001\end{array}$ & $\begin{array}{c}0.55740 \\
0.0384\end{array}$ & 1.00000 \\
\hline & Female & $\begin{array}{c}0.54779 \\
0.0426\end{array}$ & $\begin{array}{c}0.59054 \\
0.0262\end{array}$ & $\begin{array}{c}-0.2881 \\
0.3397\end{array}$ & $\begin{array}{c}0.40569 \\
0.1690\end{array}$ & $\begin{array}{c}0.33483 \\
0.2634\end{array}$ & $\begin{array}{c}0.86698 \\
<.0001\end{array}$ & $\begin{array}{c}0.96176 \\
<.0001\end{array}$ & 1.00000 \\
\hline
\end{tabular}

Pair-wise correlation coefficients and p-values are in parenthesis.

\section{EMPIRICAL RESULTS}

Descriptive statistics for the various measures of dependent and independent variables are presented in Table 1. Relatively smaller standard deviation (1683.19) of CPCU members with a mean of 26,656.80 does not indicate much fluctuations in the aggregate membership from year to year. However, Graph-1 and Graph-2 both depicts a disturbing declining trend in the CPCU membership and also in their conversion rate of membership. Table-1 reveals that "Male" GMAT takers outnumbered "Female" by more than 2:1 in the 35-39 age category, they also outnumbered "Female" in the 40-49 age category. However, they are equally likely at younger age. This 
suggests that due to some unobservable factor(s) female GMAT takers decline in the higher age groups. Thus, the idea of this exploratory analysis is to observe the association between CPCU members and GMAT exam takers by gender.

Simple pair-wise correlation analysis (see Table-2) among the variables, reveal that GMAT takers and CPCU members are negatively correlated at the 0.01 significance level for the age group 20-25 years. However, the relationship is positive for the higher age groups. It is possible that understanding the importance of becoming a CPCU society member requires experience and maturity. Therefore, the relationship reverses for the younger age groups when time period is delayed by five years and thus supporting our above hypothesis.

Table 3: Regression results of CPCU members (Female) on GMAT takers.

\begin{tabular}{|l|c|c|c|c|c|}
\hline \multicolumn{7}{|c|}{ Analysis of Variance } & F Value & Pr $>$ F \\
\hline Source & DF & $\begin{array}{c}\text { Sum of } \\
\text { Squares } \\
\text { Square }\end{array}$ & 6401927 & 10.09 & 0.0031 \\
\hline Error & 3 & 19205781 & 634539 & & \\
\hline Corrected Total & 9 & 5710849 & & & \\
\hline R-Square & 12 & 24916630 & & 0.6944 & \\
\hline
\end{tabular}

\begin{tabular}{|c|c|c|c|c|c|}
\hline \multicolumn{6}{|c|}{ Parameter Estimates } \\
\hline Variable & DF & $\begin{array}{l}\text { Parameter } \\
\text { Estimates }\end{array}$ & $\begin{array}{c}\text { Standard } \\
\text { Error }\end{array}$ & t Value & $\operatorname{Pr}>|t|$ \\
\hline Intercept & 1 & 25648 & 2066.76722 & 12.41 & $<.0001$ \\
\hline $\begin{array}{r}\text { GMAT } \\
20 \_25 \text { (female) } \\
\end{array}$ & 1 & -0.09148 & 0.02314 & -3.95 & 0.0033 \\
\hline $\begin{array}{r}\text { GMAT } \\
\text { 35_39 (female) } \\
\end{array}$ & 1 & 1.38232 & 1.47557 & 0.94 & 0.3733 \\
\hline $\begin{array}{r}\text { GMAT } \\
\angle 0 \_49 \text { (female) } \\
\end{array}$ & 1 & -0.33398 & 1.59472 & -0.21 & 0.8388 \\
\hline
\end{tabular}

Table 4: Regression results of CPCU members (Female) on GMAT takers of 5 years lag.

\begin{tabular}{|l|c|c|c|c|c|}
\hline \multicolumn{5}{|c|}{ Analysis of Variance } & \multirow{2}{*}{ Pr $>$ F } \\
\hline Source & DF & $\begin{array}{c}\text { Sum of } \\
\text { Squares }\end{array}$ & $\begin{array}{c}\text { Mean } \\
\text { Square }\end{array}$ & F Value & 0.1628 \\
\hline Model & 3 & 10426133 & 3475378 & 2.16 & \\
\hline Corror & 9 & 14490496 & 1610055 & & \\
\hline R-Square & 12 & 24916630 & & & \\
\hline
\end{tabular}

\begin{tabular}{|c|c|c|c|c|c|}
\hline \multicolumn{6}{|c|}{ Parameter Estimates } \\
\hline Variable & DF & $\begin{array}{c}\text { Parameter } \\
\text { Estimates }\end{array}$ & $\begin{array}{c}\text { Standard } \\
\text { Error }\end{array}$ & t Value & $\operatorname{Pr}>|t|$ \\
\hline Intercept & 1 & 24444 & 3395.78657 & 7.20 & $<.0001$ \\
\hline $\begin{array}{r}\text { GMAT } \\
\_20 \_25 \text { (female) } \\
\end{array}$ & 1 & -0.01855 & 0.15109 & -0.12 & 0.9050 \\
\hline $\begin{array}{r}\text { GMAT } \\
\text { 35_39 (female) }\end{array}$ & 1 & -3.52273 & 2.40451 & -1.47 & 0.1769 \\
\hline $\begin{array}{r}\text { GMAT } \\
\_40 \_49 \text { (female) }\end{array}$ & 1 & 5.15660 & 2.42882 & 2.12 & 0.0627 \\
\hline
\end{tabular}

Results of multiple regression analysis are reported in Tables 3-6. All these models appeared to fit well in estimating the number of CPCU members. Reported coefficients of determination $\left(\mathrm{R}^{2}\right)$ are $0.77,0.42,0.75$, and 0.93 respectively, with highly significant $\mathrm{F}$ values. Results indicate that younger individuals in general are less likely to 
become a CPCU society member than older GMAT takers (see Tables 3-6). Analysis also reveals that, higher age group females after five years delay are more likely to join CPCU society than their male counterpart.

Therefore, individuals' gender may affect the decision to become CPCU society member depending on their age groups. Specifically, given five year delay, female GMAT takers will join the society at a higher rate than the male GMAT takers. A number of possible explanations can be explored for this age dependent gender effect. However, considering that the average age of a CPCU enrollee is about 31 years, competing time for family care could be a major aspect and gender differences in time spent on family care is well-documented. This study suggests that gender effect is age dependent and more specifically the gender effect is significant for individuals in the higher age categories.

Table 5: Regression results of CPCU members (Male) on GMAT takers.

\begin{tabular}{|c|c|c|c|c|c|}
\hline \multicolumn{6}{|c|}{ Analysis of Variance } \\
\hline Source & DF & $\begin{array}{l}\text { Sum of } \\
\text { Squares }\end{array}$ & $\begin{array}{c}\text { Mean } \\
\text { Square }\end{array}$ & F Value & $\operatorname{Pr}>\mathbf{F}$ \\
\hline Model & 3 & 18697605 & 6232535 & 9.02 & 0.0045 \\
\hline Error & 9 & 6219025 & 691003 & & \\
\hline Corrected Total & 12 & 24916630 & & & \\
\hline R-Square & 0.7504 & & Adj R-Sq & 0.6672 & \\
\hline
\end{tabular}

\begin{tabular}{|c|c|c|c|c|c|}
\hline \multicolumn{6}{|c|}{ Parameter Estimates } \\
\hline Variable & DF & $\begin{array}{c}\text { Parameter } \\
\text { Estimates }\end{array}$ & $\begin{array}{c}\text { Standard } \\
\text { Error }\end{array}$ & t Value & $\operatorname{Pr}>|t|$ \\
\hline Intercept & 1 & 26800 & 2113.20088 & 12.68 & $<.0001$ \\
\hline $\begin{array}{r}\text { GMAT } \\
\_20 \_25 \text { (male) } \\
\end{array}$ & 1 & -0.06313 & 0.01953 & -3.23 & 0.0103 \\
\hline $\begin{array}{r}\text { GMAT } \\
\text { 35_39 (male) }\end{array}$ & 1 & -0.34766 & 0.35186 & -0.99 & 0.3489 \\
\hline $\begin{array}{r}\text { GMAT } \\
40 \_49 \text { (male) }\end{array}$ & 1 & 1.09111 & 0.57394 & 1.90 & 0.0897 \\
\hline
\end{tabular}

Table 6: Regression results of CPCU members (Male) on GMAT takers of 5 years lag.

\begin{tabular}{|l|c|c|c|c|c|}
\hline \multicolumn{5}{|c|}{ Analysis of Variance } & Pr $>$ F \\
\hline Source & DF & $\begin{array}{c}\text { Sum of } \\
\text { Squares }\end{array}$ & $\begin{array}{c}\text { Mean } \\
\text { Square }\end{array}$ & F Value & $<.0001$ \\
\hline Model & 3 & 23303786 & 7767929 & 43.35 & \\
\hline Corror & 9 & 1612843 & 179205 & & \\
\hline R-Square & 12 & 24916630 & & & \\
\hline
\end{tabular}

\begin{tabular}{|l|c|c|c|c|c|}
\hline \multicolumn{7}{|c|}{ Parameter Estimates } \\
\hline Variable & DF & $\begin{array}{c}\text { Parameter } \\
\text { Estimates }\end{array}$ & $\begin{array}{c}\text { Standard } \\
\text { Error }\end{array}$ & t Value & Pr $>|\mathbf{t}|$ \\
\hline Intercept & 1 & 27399 & 1145.53178 & 23.92 & $<.0001$ \\
\hline $\begin{array}{c}\text { GMAT } \\
\text { 20_25 (male) }\end{array}$ & 1 & -0.06929 & 0.03199 & -2.17 & 0.0585 \\
\hline $\begin{array}{c}\text { GMAT } \\
\text { 35_39 (male) }\end{array}$ & 1 & -1.35554 & 0.13842 & -9.79 & $<.0001$ \\
\hline $\begin{array}{c}\text { GMAT } \\
\text { 40_49 (male) }\end{array}$ & 1 & 2.46978 & 0.40007 & 6.17 & 0.0002 \\
\hline
\end{tabular}




\section{CONCLUSION}

This study, examines the effect of age based gender effect on the process of joining CPCU society. In particular, statistical significance and magnitude of GMAT takers dependent on age and gender influence on the "CPCU membership" is observed. As expected, after controlling for younger age categories, higher age category (more mature and experienced) is found to be instrumental in affecting the process of CPCU society's membership trend. This suggests that gender influence on the process of society membership is age dependent in GMAT takers sub-population. Furthermore, gender effect is substantially higher for older individuals compared to younger people. This predictive power of age dependent gender on the membership trend is most significant after five years of time delay.

\section{AUTHOR INFORMATION}

Askar Choudhury is a Professor of Management and Quantitative Methods at the College of Business, Illinois State University. He holds a Ph.D. in Business Administration from the Arizona State University. Dr. Choudhury teaches in the areas of business statistics, time series analysis, forecasting, operations management, and graduate quantitative methods courses. He has authored and co-authored over 38 refereed journal articles and presented numerous papers regularly at national/international academic conferences. His primary research interests include prediction modeling, time series analysis, co-integration analysis and development of statistical methodologies for application in business and health sciences.

James Jones is the Director of Katie Insurance School. He works with insurance industry, College Dean, and faculty in helping to prepare undergraduate students for careers in insurance. Also develops and facilitates professional development and executive education, and oversee and facilitates faculty research on insurance industry issues. Prior to that he was Director of the Center for Performance Improvement and Innovation for American Institute for CPCU. Worked in various roles in insurance industry for 15 years. Served as director on several insurance association boards.

\section{REFERENCES}

1. Addison, J.T. \& Schnabel, C. (2003). International handbook of trade unions, Edward Elgar Publishing, 1 edition.

2. Biezen,I.V. \& Mair, P. (2001). Party Membership in Twenty European Democracies, 1980-2000, Party Politics, Vol7. No.1 pp5-21.

3. Bureau of Labor Statistics, U.S. Department of Labor, news lease, January 2010.

4. Choudhury, A. (1994). Untransformed first observation problem in regression model with moving average process. Communications in Statistics: Theory and Methods, 23(10), 2927-2937.

5. Choudhury, A., Hubata, R., \& St. Louis, R. (1999). Understanding time-series regression estimators. The American Statistician, 53(4), 342-348.

6. Choudhury, A., Jones, J.R., Gamage, J., \& Ostaszewski, K. (2008). Structural change in the CPCU curriculum and its effect on the completion time. Academy of Educational Leadership Journal, 12(2), 95108.

7. Everson, D. H. (1982). The Decline of Political Parties, Proceedings of the Academy of Political Science, Vol. 34, No. 4, The Communications Revolution in Politics, pp. 49-60.

8. Hocking, R.R. (1976). The Analysis and Selection of Variables in Linear Regression, Biometrics, Vol.32, No.1., pp.1-49.

9. Kaufman, B.E., \& Kleiner, M.M. (1993). Employee representation: alternatives and future directions, Industrial Relations Research Association, Business \& Economics.

10. Klingemann, H. \& Fuchs, D. (1998). Citizens and the State, Oxford University Press, Beliefs In Government, Vol. 1.

11. Neumann, G. R. \& Rissman, E.R. (1984). Where Have All the Union Members Gone? Journal of Labor Economics, Vol. 2, No. 2, Essays in Honor of Melvin W. Reder, pp. 175-192.

12. Scruggs, L. \& Lange, P. (2002). Where Have All the Members Gone? Globalization, Institutions, and Union Density, the Journal of Politics, Vol. 64, No. 1, pp. 126-153. 
13. Selle.P. (1991). Membership in Party Organizations and the Problem of Decline of Parties, Comparative Political Studies, Vol.23, No.4, 459-477.

14. Steven, M. (1990). The relationship between membership decline and union commitment: A field study of local unions in crisis, Journal of Applied Psychology, Vol. 75(3), 258-267.

15. Tan, A.(1995). Party Transformation and Party Membership Decline-The Case of the Netherlands.

16. Visser, J. (2006). Union Membership Statistics in 24 Countries, Monthly Labor Review Online, Vol.129, No.1.

17. Waddington, J. \& Whitston, C. (1997). Why Do People Join Unions in a Period of Membership Decline? British Journal of Industrial Relations, 35:4 0007-1080, pp.515-546.

18. Wattenberg, M. P. (1998). The Decline of American Political Parties, 1952-1996, Harvard University Press, Fifth Edition. 


\section{NOTES}

